Revista Bioética

\title{
ATUALIZAÇÃO
}

\section{Alasdair Maclntyre's writings on medicine and medical ethics}

Patricia Souza Valle Cardoso Pastura ${ }^{1}$, Marcelo Gerardin Poirot Land ${ }^{2}$

1. Departamento de Pediatria, Instituto Fernandes Figueira, Fundação Oswaldo Cruz (Fiocruz), Rio de Janeiro/RJ, Brasil 2. Departamento de Pediatria, Universidade Federal do Rio de Janeiro (UFRJ), Rio de Janeiro/RJ, Brasil.

\begin{abstract}
Alasdair MacIntyre is a contemporary philosopher of Ethics and Politics best known for his book "After virtue", 1981. The originality and relevance of this work lie in the presentation of his articles from the 1970's about medicine and medical ethics, which are unexplored in Bioethics. In these articles, Maclntyre criticizes changes in society transforming the physician-patient relationship: fragmentary moral views, individualism, misunderstanding of scientism and fallibility of the practice, as well as the lost background of common values and medical authority. From a teleological perspective, MacIntyre describes internal goods of medicine and physician's virtues: reliability, fairness, courage, humility and even, friendship.
\end{abstract}

Keywords: Ethics, medical. Bioethics. Professional practice. Physician's role. Physician-patient relations.

\section{Resumo}

\section{Escritos de Alasdair MacIntyre sobre medicina e ética médica}

Alasdair Maclntyre é um filósofo contemporâneo de ética e política, mais conhecido por seu livro "Depois da virtude", 1981. A originalidade e a relevância deste trabalho estão na apresentação de artigos escritos por ele nos anos 1970 sobre medicina e ética médica, inexplorados no campo da bioética. Nestes artigos, Maclntyre critica as mudanças na sociedade que transformam a relação médico-paciente: visões morais fragmentárias, individualismo, a incompreensão da cientificidade e falibilidade da prática, além das perdas do embasamento em valores comuns e da autoridade médica. Em perspectiva teleológica, Maclntyre define bens internos à medicina e virtudes que os médicos devem possuir: confiabilidade, justiça, coragem, humildade e até amizade.

Palavras-chave: Ética médica. Bioética. Prática profissional. Papel do médico. Relações médico-paciente.

\section{Resumen}

\section{Escritos de Alasdair Maclntyre sobre medicina y ética médica}

Alasdair Maclntyre es un filósofo contemporáneo de Ética y Política, mejor conocido por su libro "Tras la virtud", de 1981. La originalidad y relevancia de este trabajo se encuentran en la presentación de sus artículos de la década de 1970 sobre medicina y ética médica, que no han sido explorados en Bioética. En estos artículos, MacIntyre critica los cambios en la sociedad que transforman la relación médico-paciente: visiones morales fragmentarias, individualismo, incomprensión del cientificismo y la falibilidad de la práctica, además de las pérdidas de la base en valores comunes y la autoridad médica. En una perspectiva teleológica, Maclntyre describe los bienes internos de la medicina y las virtudes de los médicos: fiabilidad, justicia, coraje, humildad e incluso amistad.

Palabras clave: Ética médica. Bioética. Práctica profesional. Rol del médico. Relaciones médico-paciente.

Declaram não haver conflito de interesse. 
Alasdair Chalmers Maclntyre is a contemporary philosopher well known for his book "After virtue" ${ }^{1}$, of 1981 . He is considered an important representative of Communitarianism and Virtue Ethics schools of thought, although he denies both linkages and identifies himself as a Thomist ${ }^{2}$. Above all he is a critic of modernity, of the Enlightenment and emotivism. He defends narrative traditions of subjects in a teleological view of life.

In philosophy, he is recognized for his works regarding moral and politics. But in Bioethics, as ethics applied to health, there are only a few works about his theories, which bring references almost exclusively from "After virtue". In fact, Maclntyre wrote as many as 30 books and at least 5 of them are among the most studied in moral philosophy. He also wrote approximately 200 journal articles and some book reviews, which are usually less explored in Bioethics ${ }^{2}$. Some of the articles written in the 1970's specifically analyze medical ethics, medicine and its methods. It is interesting to point out from his biography that his parents were both physicians.

This essay aims to introduce and summarize the main ideas of these articles on medicine and Medical Ethics, emphasizing the fact that they were written concomitantly with the beginning of Bioethics as a formal discipline and a median 5 years before "After virtue". In many of them we can find the expressions, examples and frameworks he uses in the book to develop his philosophical perspective.

This review manuscript also intends to reclaim and update Maclntyre's criticism of: 1 ) the contemporary medical practice; 2 ) the individualistic and passive role played by patients and generally by the whole of society; and 3) medical authority lost from a historicist background of common values and beliefs.

\section{Visions of medicine and medical ethics}

Aristotle $^{3}$ says medicine is not art because it has an end other than itself - medicine aims at the patient's health. Based on those teleological Aristotelian concepts, medicine for Maclntyre is a human practice that pursues some internal goods or ends, by means of the cultivation of virtues ${ }^{4,5}$. Medical science is committed to patients prospering and flourishing ${ }^{5,6}$.

Consider a culture where there is a clear and established view of the good for man and where there is a rational consensus of the hierarchy of human goods. The good of health is entrusted to the medical profession with its concomitant virtues ${ }^{7}$.

So, for him, the flourishing of medical practice requires a shared vision of the internal goods for that practice and shared beliefs about the allocations of roles and rights within the practice to achieve those goods ${ }^{4}$. Maclntyre ${ }^{4}$ also describes the external goods of medicine, goods regarding the successful practice of medicine: power, money and fame.

Initially within this concept of socially established practice and with no reference to a scientific enterprise, Maclntyre defines medicine in its interpersonal relationships, which includes the caring presupposed by practice. Specifically in regard to caring, he believes that it has two dimensions: we care for some particular individual who stands in some relationship with us and we care for him or her in respect to some need. We may fail to care if we do not address them as they are or if we do not address what they really need ${ }^{8}$.

To approach individual needs in particular cases, physicians should have some ability to judge prudently. For Macintyre ${ }^{4}$, the capacity for good judgments is entrusted to certain individuals by virtue of recognizing that they have some experience. And judgments are especially important in dilemmatic situations of medical practice. So, Maclntyre, not alien to it all, writes about medical problems and medical ethics problems of the contemporary world, in almost every text we approach here.

Starting from the classic problems of euthanasia and abortion, he considers all moral debates of our culture as disagreements on some particular issues, which lead back to assertions of incompatible premises. Just like we can read in the first chapter of "After virtue", in many of his previous texts he explains incommensurability ${ }^{4,5,9}-$ a term he recognizes to have borrowed from the philosophy of science ${ }^{4}$. The arguments move validly from premises to conclusions, but there is no criterion available, no rational procedure to decide between rival and incompatible conclusions ${ }^{4}$.

He exemplifies with the case of abortion and it is remarkable that, despite being a catholic philosopher, he does not base it on divine commandments. He recognizes valid contextualized arguments in respect for fetus rights to life as well as women's rights to decide without coercion, while the fetus is essentially a part of the mother's body. He concludes there is no neutral court of appeal, so outcome is invariably an impasse ${ }^{4,5,9}$. 
But not only valid arguments are different, but also the contexts in which arguments are used are different from the ones where they were once created. There is no way to compare them or measure their strengths. Maclntyre repeats that fragmentary moral views are actually torn from their contexts ${ }^{4,5,9}$. It is a case of medical ethics as well as contemporary moral philosophy ${ }^{5,9}$. And his conclusion sets the general character of moral problems in our culture as a state of confusion that is dignified with the use of the expression "moral pluralism" ${ }^{4}$.

The crisis in medical ethics is not only the outcome of those rapid successive changes in society through the last century (20th) as described above, but also results from changes that occurred in medicine itself. And for Maclntyre, the real problem is that those changes were not concomitant with a redefinition of the physician's role. The battle of physicians was primarily with the major infectious diseases, as applied scientists that offer chemicals to restore physiological states without any concern over social and emotional backgrounds ${ }^{5}$. The three ends of medical practice were to postpone death, to prevent pain and disability, and to promote patients general well-being.

These ends fell apart with contemporary medicine and technology. Major mortality causes changed from infectious diseases to three chronic conditions: heart disease, strokes and cancer ${ }^{5,10}$. This situation, he says, is at odds with the inherent role which physicians were called upon to play. Now, physicians frequently prolong suffering or extend disability. Their task, now, is to make frequently harsh choices - medicine became a moral task ${ }^{5}$.

There were also some historical changes in complex institutional settings and Maclntyre ${ }^{10,11}$ discusses this issue in some publications as the bureaucratization of medicine. Mobility and the division of labor have, to a large extent, destroyed the traditional physician-patient relation ${ }^{4,11}$. In fact, in bureaucracy a physician is replaceable and patients just happen to be what is on their files ${ }^{10,11}$.

Specialization of modern medicine as applied science, despite all progress of theoretical knowledge, also justifies the way patients are not seen as persons, but rather as parts of their bodies. The personal understanding of the patient is lost by specialists ${ }^{5,11}$. But the worst problem of medical bureaucratization for Macintyre ${ }^{10}$ is not only the fact that it becomes impersonal, but that it leads patients to seek individualism.

The liberal individualistic concept of our culture is reflected in the way physician-patient relationships occur. Under modern conditions there is a contract between doctor (or, even the hospital) and patient in which technical services are exchanged for payment ${ }^{11}$. His question is: What is wrong with conceiving the doctor-patient relationship as primarily contractual? If physicians fail with the patient it is not the breach of contract that matters, but that those actions cause gross injury to a caring relation.

Macintyre illustrates with the case of marriage marriage involves a contract, but what is wrong with adultery is not primarily that it is a breach of contract; it is a gross injury to a caring relation (commitment). And he adds that nowadays physicians are not understood as individual entrepreneurs but as having roles within the cooperative life of medical institutions ${ }^{11}$. And problems of medical ethics therefore can be seen as secondary to the problems of medical organizations ${ }^{5}$.

Economic competitiveness is one aspect of moral arbitrariness ${ }^{4,12}$. Other aspects are individualism (he speaks of the acids of individualism) and the pluralism of our culture. Didactically in many of the texts, Maclntyre summarizes contemporary medical problems and medical ethics problems as pertaining to three different groups, each of them concerning the relationship of practice to some internal good of medicine.

The first are the problems that arise from technological support, which enables life preservation even if health cannot be restored or if, in so doing, pain and suffering will be increased ${ }^{8}$. For Maclntyre, to preserve life is not to be based on principles, as Albert Schweitzer defends in his theory of reverence for life. The Bible speaks of respect for living things but nothing of the sanctity of life ${ }^{13}$. So, there is still need for evaluation of specific cases, instead of preserving life against all odds.

The second point of the framework is related to the loss of a shared and socially established morality which allowed physicians to assume that the patient's attitudes towards life and death would be roughly the same as their own and vice-versa - beliefs about suffering, death and human dignity. In that former scenario, patients could have a minimal assurance that their beliefs would be respected and therefore they could trust the physician. So, Macintyre admits a very special concern for modern medicine because the whole nature of medical care is almost unimaginable without a context of mutual trust.

The third point concerns resources allocation in health care. There were changes in the scale and 
cost of medical care as well as political and economic changes in society at large that have turned the distribution of medical care into a very different issue. Medicine is now a social practice disputing resources with others. Access to medical care became unequal. Demands for social justice and the demands of the physician for autonomy are now in radical conflict.

All these situations determine certain patterns of medical care for Maclntyre ${ }^{9}$. He claims that we should not begin by asking what resources we now provide for the care of a particular group of patients and then set limits to the care that we provide. We need instead to begin from a justified standard of care, so that we can ask how, in the light of that standard, our overall resources ought to be allocated. Our budged-making should be informed by our standards and not vice-versa ${ }^{14}$.

Macintyre focuses on the contradiction between individualistic autonomy and authority. The context is of: complex forms of community with recognized centers of authority, such as schools, churches, medical facilities, dissolved into collections of individuals whose relations are governed only by negative constraints (rights) and contracts ${ }^{15}$.

In an Aristotelian sense, a moral agent without polis has a ghostly, abstract and largely disembodied existence ${ }^{16}$. In other words, he repeats that no one can be detached from all social memberships ${ }^{5}$. Besides, those conceptual changes in notions of authority, there were also changes in the notion of traditions, particularly of aging and dying. He explains that each generation finds the significance of its activity as part of a history, which transcends it ${ }^{4}$. In our contemporary culture, the significance of the present is in the present; aging and dying are threats he denotes this process as the fetishism of youth.

The pessimist conclusion Maclntyre ${ }^{9}$ comes to regarding historical and cultural changes affecting medical practice is that it has become problematic precisely at the time when there are minimal resources for the solution of moral problems. This pungent criticism of contemporary world and its moral pluralism, the criticism of enlightenment individualism, and the loss of a moral standard and teleological view is something we already imputed to Maclntyre as we know subsequent works, especially "After virtue" ${ }^{1}$. Also, we could infer his defense of medical practice as provided with internal goods and virtues of physicians.

What is unexpected is the approach to medicine not as a profession, but medicine understood as a science. Gorovitz and Maclntyre ${ }^{6}$ in the text "Toward a theory of medical fallibility" reject the view that moral problems of medicine spring primarily from its professional character. In fact, they result from its scientism. With the objective to demonstrate why medical errors occur and to distinguish between culpable and innocent error, they explore the scientific character of the method of medicine, which determines many uncertainties.

Gorovitz and Maclntyre ${ }^{6}$ initially state that ignorance of what is not yet known is the permanent state of all sciences and a source of error even when all internal norms are fully respected. Internal norms are those deriving from the essential character of scientific activity as a cognitive one. They determine professional standards to pursue and are concerned with factors such as verifiability, truth and reason. On the other hand, external norms are those governing motives either for participating in or making use of the results of scientific activity. Examples of external norms are curiosity, ambition and social utility.

Gorovitz and Maclntyre ${ }^{6}$ describe scientific method as the search for law-like standards for some properties that lead to predictions, by generalization. That is why predictions fail and the most important font of error in science is ignorance (a non-culpable font of error). Other main sources of error in pure and applied sciences, they state, are willfulness and negligence, referring to external norms of the scientific enterprise.

But applied sciences are commonly held to differ from pure sciences, as well as from technology. They are defined with an essential reference to practical aims, which is what distinguishes them from pure science. Technology refers to the devices for realizing certain ends. Applied sciences are prone to another source of error that Gorovitz and Maclntyre ${ }^{6}$ called necessary fallibility in respect to particulars. It refers to ignorance of contingencies regarding the context (particular), such as uncontrollable environmental factors. Individual characteristics will not typically be inferable simply from what is known about the whole. Generalizations apply typically to the majority of cases, while incertitude exists over particulars.

Gorovitz and Maclntyre ${ }^{6}$ consider medicine as an applied science and exemplify that therapeutic effects in individual patients are always, to some extent, uncertain. Mistakes will inevitably be made due to the inherent limitations in the predictive powers of an enterprise that is concerned essentially with the flourishing of particulars ${ }^{17}$. And they consider this phenomenon as a fundamental epistemological feature of a science of particulars.

At this point Gorovitz and Maclntyre ${ }^{6}$ reject traditional thought regarding medicine and sciences 
in general as nonmoral or morally neutral. They exemplify with Nazi experiments in concentration camps: they respected internal norms of science in pursue of truths and problem solving but they had no concern over social or individual effects. They were breaking not only external norms, but also, internal ones, for it is not possible in the authors view to study particulars (or individuals) without understanding them in their own striving toward their own good.

They reach to an important conclusion about medicine as a science: because it implicates individuals, values are internal goods of medicine, just like the search for truth and problem solving. In other words: if science is concerned with particulars then, statements of facts are not value free ${ }^{6}$.

Standing for a value-based Ethics, Macintyre ${ }^{12}$ repudiates the suggestion that the value of one life can be weighed against another in a consequentialist way. To treat an agent (a patient) with moral respect is to look to his or her dignity and not his or her happiness ${ }^{9}$. For utilitarianism in all its versions aspires to provide a criterion, a way of judging between rival and conflicting goods to maximize utility. And he repeats that the goods and the rights of our contemporary conflicts are incommensurable - there is no higher criterion, no neutral concept of utility ${ }^{9}$.

As an Aristotelian he believes that decisions should not be based on the consequences of the actions, nor should the practice of the virtues be a mean to some other end ${ }^{12}$. Macintyre, then, is also opposed to deontology, with its emphasis on the logical independence of the realm of value from the realm of fact $^{9}$. Contemporary moral philosophy and Ethics are unduly concerned with rules, their justification and status $^{5}$. Maclntyre explains deontology this way:

If our natural inclinations are no longer transformed and redirected by our dispositions, we look for a motive for right action that will be independent of those inclinations, and we sometimes find it in a sense of duty, in a regard for what moral precepts require of us, independently of any conception of our directedness toward the human good ${ }^{18}$.

But rules are less fundamental than roles and relationships in Maclntyre's view ${ }^{5}$. Virtues are the ones that should inform judgments ${ }^{5,8}$. And it is not possible to make human beings virtuous by enacting and enforcing laws. He says that laws are not obeyed due to their coercive power. Instead, because when the legal system is in order, laws encourage the exercise of virtues towards the achievement of human good ${ }^{8}$.

\section{Role of physicians}

For Maclntyre ${ }^{9}$, morality in medicine is in a special way autonomous. The medical profession has had to safeguard and transmit its values in a variety of social contexts. And for him the values to which it is committed are to preserve life and health, the responsibility for justifying patients' trust, and the demands for autonomy in judgments and resources allocation ${ }^{5,9}$. Macintyre repeats those three internal goods of medicine, also using this conceptual framework to denote the physician's virtues necessary for practice and applied ethics ${ }^{9,12}$. We see another return to Aristotle in this suggestion for physicians to act virtuously ${ }^{9}$.

To preserve life, however, is not to subscribe to a culturally powerful form of idolatry of the body, especially of a young body. Maclntyre ${ }^{12}$ criticizes the extraordinary financial and moral investment of our culture in attempts to defeat aging and death, attempts that express resentment towards the condition of finitude. He also approaches those problems of end of life in the context in which physicians must be wise and prudent in order to recognize that many patients are incurable ${ }^{5}$. The same applies to treating a physically imperfect or crippled child with a needless bundle of distorted and suffering nerves and tissues ${ }^{19}$ - an example he uses.

When Maclntyre writes about truthfulness he emphasizes that physician lying to someone about the nearness of their death is specially prohibited because to approach death is to approach God's judgment. Each of us is required to approach our own death with acts of conscious preparation, and if physicians deny this possibility to someone, then they inflict a gross wrong on that person ${ }^{12}$ - physicians insult that person's status as a human being ${ }^{9}$.

Justice and resource allocation is the third piece of Maclntyre's framework that has implications for the politics and economics of health care. But when he approaches this topic of contemporaneous medical practice, he does not directly name virtues, but attitudes. We could think of courage, responsibility and reliability, wisdom and prudence as other ways to characterize those omitted medical virtues. In fact, when Maclntyre ${ }^{9}$ writes about traditional medical virtues he takes reliability, fairness, and courage for granted. Fairness, he says, requires that we treat others in respect of merit according to uniform and impersonal standards. Courage is the capacity to risk harm or danger to oneself - it has its role in human life because of its connection with care and concern ${ }^{9}$. 
Macintyre ${ }^{8}$ sorts virtues as other-regarding (justice and generosity) and self-regarding (temperateness). But for him, self is not one thing and its social relationships, another. Virtues are constitutive parts of what we are, and the good of each individual is not the good of that individual in isolation from others, but the good of that individual in relationships with others. Engaging in those types of conversation and those types of practice enables us to be mutually instructed about what our common good is. He says:

It is only insofar as we are disposed to give others a just hearing, to be generous in our interpretation of what they say, to be temperate in the expression of our own views, to take risk in exposing such views to refutation and to be imaginatively sympathetic in our appreciation of opposing standpoints that we are able to participate constructively in such conversations and such practices ${ }^{20}$.

And this statement applies perfectly to physicians in their practice of hearing and valuing to reach diagnoses and choosing the best way to heal or alleviate suffering; especially with temperateness and sympathy. It take us to the point where patients are objects of the physician's benevolence, recipients of their giving's. But Maclntyre explains that we are all vulnerable to further disease, and due to that vulnerability we are often actually, and always potentially, dependent on others for care.

When physicians provide care they must do what is best for patients by enabling them, as far as possible, and as soon as possible, to become independent - to become able to define their own needs again. This discussion is closest to that undertaken by MacIntyre in the book "Dependent rational animals" from $1999^{21}$. He highlights the networks of giving and receiving, sustained by shared recognition of each other's needs ${ }^{8}$.

The other virtue Maclntyre mentions is humility. Physicians should have attitudes of humility both regarding the state of development of medical knowledge and the richness and diversity of individuals. And for him, it goes beyond good clinical practice, which already involves respect for the importance of individual distinctiveness present in the individual's medical history ${ }^{6}$.

An important virtue to Aristotle that Macintyre remarks on as never being mentioned in modern books of moral philosophy is friendship. Friendship in the Aristotelian sense happens when persons linked by their concerns for goods that are the same ones.
Friendship is not based on pleasure in each other's company or on mutual benefit. Macintyre ${ }^{5}$ adds that when there is friendship, the physicians exercise a sensitive judgment on their patient, on their behalf. Otherwise the relationship is purely contractual.

Finally, Maclntyre approaches the need physicians have to exercise authority for making clinical judgments regarding singular cases in practice. Exercise of authority involves accumulation of experience and transmission of traditions. Authority and tradition provide the necessary conditions for the exercise of rationality. He repeats it many times: moral authority is embodied in social rules practices and communities - church, state, family, school ${ }^{4,5}$. In medicine as well as in education the recognition of authority and the concept of a profession are inseparable. The assumption of responsibility has no necessary connection with the possession of technical skills, though flourishing of traditions and acceptance of authority from those engaged in a practice requires a high degree of moral consensus - requires a shared vision of the goods internal to that practice, shared beliefs about procedures necessary to achieve these goods and about the allocation of roles ${ }^{22}$.

Unfortunately, Maclntyre also denotes great pessimism about the rescue of traditional medical authority in the contemporary world. Social and intellectual contexts have changed too much. We are actually strangers to each other and each human being's self-preservation is only his or hers own business ${ }^{4}$.

\section{Patients}

In one of the texts Maclntyre identifies himself within the role of a patient which enables him to report patients' feelings and sensations while they face bureaucratic medicine and changes in a pluralistic society ${ }^{10}$. He says that modern medicine is inescapably and unavoidably bureaucratic in its form, and this concept applies to large organizations as well as small hospitals or private practice.

Some examples of bureaucracy, he reports, are regarding access to the physician, when patients wait in line for medical appointments or exams, and especially in the fact that it is the role that matters, not the individual. The term substitutability is applied to physicians that can be replaceable, due to their own mobility and because what matters is who happens to be on duty ${ }^{10}$. For patients, who move as well, the scenario he describes is the one 
where persons are substituted by files. Maclntyre says that if patients are treated in a bureaucratic way they are not treated as persons, which reinforces the passivity peculiar to the sick-role ${ }^{10}$.

Disappointment is the feeling that summarizes those experiences of a divorce between expectations and reality - when patients only wants to recognize themselves as healthy and physicians want to treat a set of identifiable diseases ${ }^{10}$. Then, the impersonality resulting from bureaucracy forces patients into attitudes of dependency - not only because they approach healthcare in need, but because it is bureaucracy that will tell the clients what they need ${ }^{10}$.

Maclntyre also describes impersonality when specialized physicians treat only parts of patients' bodies. The patient is not a whole person, but a collection of parts of the body or subsystems. And he says that impersonality due to specialization deprive the patient of moral and social dimensions ${ }^{10}$. He concludes that if impersonality coexists with a quite individualistic way of thinking about the doctorpatient reality, then it is also a negative result of the individualistic ideology of modernity ${ }^{10}$.

Macintyre rejects this individualist role patients assume, instead of acceptance of physicians authority. Traditionally patients put themselves in the doctor's hands and allows him or her to have the responsibility. It is not necessary for doctors to reveal their own process of thinking, making the patient a victim of all information. In a relationship that is more than contractual, the physician tells the patient assertively just what is necessary ${ }^{4,10}$. Once again, Maclntyre exemplifies the differences between contractual and caring relations, comparing the patient's relationship with his or hers physician to the customer's relationship with the restaurant owner ${ }^{4}$. The client is free to choose in what restaurant to eat and what to eat and the restaurant owner acts under certain constraints, such as the maintenance of hygienic standards; but both are autonomous.

A characteristic of modern society is the tendency to over value autonomy - we now speak of consumerism in medicine. Maclntyre, in other words, would say the same: if a patient freely chooses one particular physician, then there is a contract between doctor and patient in which technical services are exchanged for payment ${ }^{11}$. So, he adds, it is a gross error to suppose that to respect a patient as a person it is necessary to respect his or her autonomous choices regarding health problems ${ }^{10}$.

In fact, according to Maclntyre, a patient only believes he or she is the one to make his or hers own choices over treatment because he and the physician have no common background of values and beliefs. Nobody really can rely on anyone else's judgments on their behalf until they know what the other person believes. Maclntyre speaks of a form of moral autonomy as a social condition ${ }^{4}$.

Autonomy, in this way is not as it is for Kant, a property of every rational agent. Maclntyre believes in autonomy as an achievement, a social achievement: It is in and through our network of relationships that we achieve rational control of our lives ${ }^{23}$. And it is clearly related to patients that should not see themselves as individuals with a set of unordered needs and wants, apart from social relationships and without defined roles which constitute the telos of their lives ${ }^{10}$.

Maclntyre ${ }^{10}$ even makes some criticism regarding the contemporary definition of "person", in the Oxford English Dictionary: "bearer of legal rights". For he explains that in Hebrew, Aramaic or Greek there are no words that could be correctly translated by this expression: a right ${ }^{11}$. Not even the Bible has room for such a concept. The same way as with the definition of "person", Maclntyre ${ }^{12}$ defines "patient" in its etymological conception - as passive recipients - in order to criticize the passive role patients often assume. They assume passive roles when they face bureaucracy, face the contractual model they appeal to and when they attribute to physicians some magical role, ignoring the scientific character of medical practice ${ }^{10,11}$.

Maclntyre makes us aware of the paradox of patients' situation. They stand passively in the position of victims, but they want to make all decisions over life and death, and claim autonomy. And they are the ones who assume such antagonist positions. Patients are persons in our liberal society - they deny traditions, doctor's authority and want to assume their individualism. So, one of the most important conclusions of Maclntyre is this change in paradigm.

We have failed to solve the problems of medical ethics because we have presupposed a wrong answer to "whose problems are they?" The answer taken for granted is: physicians, nurses or hospital administrators. But they are problems of patients. That is why Maclntyre highlights patients' roles as moral agents, as opposed to autonomous individuals. Patients must be active ${ }^{4}$. Then, he gives many examples as to how patients can play active parts in hospital life, learning facts about the medical fallibility and the clinical methodology, instead of projecting onto the physician the role of magician or someone who can defeat death. 
Bureaucracy itself, explains Maclntyre, acts to blind patients from the facts about medical error. Patients have to learn not only that doctors in general make mistakes, but also that making mistakes is a part of the scientific method, as well as that clinical judgment improves with experience ${ }^{6,10,11}$. What patients do instead is to believe in science as magic, a powerful and unfailing enterprise. But science claims to knowledge and magic to power ${ }^{24}$.

People in our culture, he adds, believe in magic rather than religion because magic controls power while religion puts us in the hands of a power we cannot control. A second difference is that salvation in religion offers no guarantee of preservation from suffering, and magic promises to make us invulnerable. What is wrong for Maclntyre is that people look to medicine not merely for the relief of pain but for something that will prevent them from growing old. They also want everything cured, even if it is necessary to look for and believe in miracle drugs: They do indeed want to become invulnerable and immortal ${ }^{24}$.

In almost all of the texts there is some mention of death and how people want to fend it off. But we will all die, and Maclntyre says patients should realize that, and instead of trying to defeat death, just be prepared for it. Society should recognize that we are all incurable at the end, and people should rely on a finalistic vision of life ${ }^{5}$.

In fact, active patients really should define their own goods, but different goods. And they should also redefine their roles. For Maclntyre, patients should be absolved of responsibility and invite the doctor to take care of them. He adds that it is incapacity that qualifies patients - it is vulnerability that puts them in that place, not autonomy ${ }^{4}$. Maclntyre concludes that no one is an abstract moral agent, but there are inter-defined roles for physicians, patients, nurses and so on. Patients should become active moral agents instead of passive ones ${ }^{4,5,10}$.

\section{Final considerations}

Despite admitting a crisis in medicine concerning medical ethics, which symptoms include the way philosophers are invited to medical schools and hospitals, Maclntyre finds that solutions are not in philosophical theorizing - Ethics and Philosophy experience the same crisis as the medical profession. In fact, he believes there are no answers to be given, as there are no moral resources in our culture that lead to real solutions.

Maclntyre stands for a pessimistic conclusion that medical ethics problems are unresolvable in our culture due to the lack of any shared background of beliefs, which could allow for moral reasoning by providing a view of the man's true end, of human nature, and society. A simplistic way to deal with Maclntyre's pessimism could be to turn to other authors that admit the liberal thought of contemporaneity. Otherwise, highlighting Maclntyre's writings of the 1970's can be a way to disclaim that traditions, narratives, values and the recognition of a person's interdependence are always internal goods of medical practice.

The conclusion of this work directed to physicians an earnest invitation to act virtuously. In relation to patients, and to society in general, it is a call take on a more active role. Patients are the ones who should understand medicine in its methodology, who should accept their own vulnerability and death, and who should play less individualistic roles. Active patients really should define their own goods, and goods in a teleological sense.

Teleology applies to physicians as well. Macintyre says: there is no way to answer the question which moral rules ought I to respect in this situation? until I have first answered the question: who am I? 25

Physician's moral choices ought not to be about alternative actions in particular situations, but regarding holistic forms of life, on holistic alternative ways of organizing roles and relationships in medical practice contexts, and about the goods to be achieved this way. So, following Maclntyre there is a new prescriptive and interpretative pathway for medical practice and medical ethics, respectively. We, the ones who live temporarily "After virtue", can benefit from Maclntyre's conceptual scheme regarding ethics, medical ethics, medical practice and life...

\section{Referências}

1. Maclntyre A. After virtue: a study in moral theory. Notre Dame, IN: University of Notre Dame Press; 1981.

2. Lutz CS. Alasdair Chalmers MacIntyre (1929-). IEP [Internet]. [s.d] [acesso 7 jul 2016]. Disponível: https://bit.ly/31RBOnm 
3. Aristóteles. Ética a Nicômaco. São Paulo: Nova Cultural; 1996.

4. Maclntyre A. Patients as agents. In: Spicker SF, Engelhardt HT Jr, editores. Philosophical medical ethics: its nature and significance. Dordrecht: D. Reidel; 1977. p. 197-212.

5. MacIntyre A. What has ethics to learn from medical ethics? Philos Exch [Internet]. 1978 [acesso 7 jul 2016];9(1):37-47. Disponível: https://bit.ly/31RDOfm

6. Gorovitz S, MacIntyre A. Toward a theory of medical fallibility. J Med Philos [Internet]. 1976 [acesso 2 abr 2018];1(1):51-71. DOI: 10.1093/jmp/1.1.51

7. MacIntyre A. Op. cit. 1977. p. 206.

8. Maclntyre A. The need for a standard of care. In: Francis LP, Silver A, editores. Americans with disabilities: exploring implications of the law for individuals and institutions. Nova York: Routledge; 2000. p. 81-6.

9. Maclntyre A. How virtues become vices: medicine and society. Encounter [Internet]. 1975 [acesso 2 abr 2018];45(1):11-7. Disponível: https://bit.ly/2MRiEd2

10. Maclntyre A. Medicine aimed at the care of persons rather than what? In: Cassell EJ, Siegler M, editores. Changing values in medicine. Frederick: University Publications of America; 1985. p. 83-96.

11. Maclntyre A. Ethical issues in attending physician-resident relations: a philosopher's view. Bull N Y Acad Med [Internet]. 1979 [acesso 4 abr 2018];55(1):57-61. Disponível: https://bit.ly/36emaWI

12. MacIntyre A. Theology, ethics, and the ethics of medicine and health care: comments on papers by Novak, Mouw, Roach, Cahill, and Hartt. J Med Philos [Internet]. 1979 [acesso 7 jul 2016];4(4):43543. DOI: $10.1093 / \mathrm{jmp} / 4.4 .435$

13. Maclntyre A. Theology, ethics, and the ethics of medicine and health care: comments on papers by Novak, Mouw, Roach, Cahill, and Hartt. Op. cit. 1979. p. 440.

14. MacIntyre A. Op. cit. 2000. p. 82.

15. Maclntyre A. Op. cit. 1977. p. 202-3

16. MacIntyre A. Op. cit. 1978. p. 41

17. Gorovitz S, Maclntyre A. Op cit. p. 64.

18. Maclntyre A. Op. cit. 2000. p. 85.

19. Maclntyre A. Op. cit. 1975. p. 16

20. MacIntyre A. Op. cit. 2000. p. 84.

21. Maclntyre A. Dependent rational animals: why human beings need the virtues. Chicago: Open Court; 1999.

22. MacIntyre A. Op. cit. 1977. p. 201.

23. Maclntyre A. Op. cit. 1985. p. 95.

24. MacIntyre A. Op. cit. 1985. p. 92

25. MacIntyre A. Op. cit. 1978. p. 46.

\section{Participation of the authors}

Patricia Souza Valle Cardoso Pastura participated in the conception of the work, literature review, data interpretation and writing of the manuscript. Marcelo Gerardin Poirot Land participated in the data interpretation and critical revision of the manuscript. Both authors approved the final version.

\section{Correspondência}

Patricia Souza Valle Cardoso Pastura - Av. Rui Barbosa, 716, Flamengo CEP 22250-020. Rio de Janeiro/RJ, Brasil.

Patricia Souza Valle Cardoso Pastura - PhD - patpastura@gmail.com

(iD) 0000-0001-7198-1481

Marcelo Gerardin Poirot Land - PhD - land.marcelo@gmail.com

(iD) 0000-0001-9792-3167 